\title{
Sacred Groves: A Pattern of Zagros Forests for Carbon Sequestration and Climate Change Reduction
}

\author{
Aioub Moradi \\ University of Kurdistan \\ Naghi Shabanian ( $\nabla$ n.shabanian@uok.ac.ir) \\ University of Kurdistan https://orcid.org/0000-0002-5462-0374
}

\section{Research}

Keywords: Zagros forests, Sacred groves, Silvopastoral lands, carbon sequestration

Posted Date: May 10th, 2021

DOI: https://doi.org/10.21203/rs.3.rs-270508/v2

License: (c) (i) This work is licensed under a Creative Commons Attribution 4.0 International License.

Read Full License 
1

3

4

5

$6 \quad{ }^{1}$ Department of Forestry, University of Kurdistan, Sanandaj, Iran. E-mail: aiuobmoradi60@gmail.com

$72^{2 *}$ (Corresponding author), Department of Forestry, The Center for Research and Development of Northern Zagros

8 Forestry, University of Kurdistan, Sanandaj, Iran. P.O.Box. 416 Tel.: +98-918-8710672

9 E-mail: $\underline{\text { n.shabanian@uok.ac.ir }}$ 


\title{
Sacred groves: A pattern of Zagros forests for carbon sequestration and climate change reduction
}

\begin{abstract}
Background: Rising atmospheric carbon dioxide has led to the global consequences of climate change. Biological carbon sequestration through vegetation and soils is one of the cost-effective ways to reduce this gas. Forest's ecosystems are the most important carbon pools among terrestrial ecosystems and play a sustainable and long-term role in reducing climate change. Among forest ecosystems, sacred groves are less-disturbed and they can be a pattern of successful forest management for carbon sequestration and climate change reduction. In the present study, for the first time, the amount of carbon content in sacred grove and silvopastoral lands were investigated to determine the capacity of Zagros oak forests in carbon sequestration and climate change reduction. The aim of this study was to estimate the amount of carbon reserves in mentioned landuses in order to obtain a systematic attitude towards management of these different land-use types and attain a suitable solution to counter the climate change crisis and ultimately sustainable environmental development.
\end{abstract}

Results: The results showed that each of the studied variables in the two studied land use is significantly different from each other. The mean of each of these biomass or carbon pools in silvopastoral is significantly lower than sacred groves. The results indicate that the common utilizations in the forests of the study area cause a significant reduction $(\mathrm{P} \leq 0.01)$ in the forest biomass value and respective carbon content. Sacred grove currently absorbs 826.96 tons of carbon dioxide per hectare more than silvopastoral lands and this is a sign of high degradation in the forests of the study area.

Conclusions: According to the results obtained in this study, forest ecosystems that are protected against human intervention play a significant role in long-term carbon storage. Any interference with the natural conditions of the ecosystem has a significant negative impact on carbon reserves. Therefore, by selecting appropriate measures, local communities should be empowered to reduce their dependence on low incomes obtained from deforestation and conversion.

Keywords: Zagros forests, Sacred groves, Silvopastoral lands, carbon sequestration 


\section{Introduction}

52 Climate change and global warming due to rising greenhouse gas concentrations is one of the 53 major challenges in sustainable development. The increase of concerns about global warming and climate change have led to special attention being paid to forests, soils, and their ability to carbon sequestration sustainably [1,2]. Vegetation and the soils covered by them are permanent pools and play a significant role in sequestering atmospheric carbon, thus reducing the effects of climate change [3]. The high capacity of forest ecosystems to decrease greenhouse gas emissions makes carbon management a key component of future natural climate solutions [4-6]. Forests are good criteria for controlling the carbon value of the atmosphere because they are the most important carbon pools for carbon sequestration [7]. Forests reserve more than twice the value of carbon in the atmosphere [8,9], about $70 \%$ of global soil organic carbon and approximately $80 \%$ of aboveground carbon $[10,11]$. Therefore, these worth ecosystems are the most important carbon pools among terrestrial ecosystems and play a sustainable and long-term role in reducing

Disruptions are one of the factors that play a key role in the ecosystem carbon dynamics [13]. Natural and human-caused disruptions in forest ecosystems significantly affect ecosystem performance $[14,15]$, and carbon balance [13]. One of the most desirable and cost-effective approach for carbon sustainability in forests, as well as counter with disruptions such as deforestation and degradation, is the conservation and development of protected forests, which has been proposed globally [16]. Protected areas are the best strategy for biodiversity protection when faced with degradation, fragmentation and ecosystem detriment [17, 18]. Sacred groves are tested and proven procedure to preservation; as a result, it can be an important and vital part of protected areas [17].

Zagros forests with an area of more than five million hectares are considered the natural ecosystems of Iran and their economic value in terms of carbon sequestration is quite vital. Despite severe and continuous traditional exploitation of the Zagros forests, some parts of forests which are believed to be sacred religious areas and cemeteries have remained untouched (less-disturbed). These areas are defined as sacred groves [17, 19]. In fact, sacred groves are forests that are less disturbed and are of special spiritual importance to people and communities. The actual appearance of the Zagros forests can be found in these sacred groves [20,21]. In sacred groves of study area about 250 plant species have been recorded [17]. 
82 These areas (sacred groves) offer a valuable opportunity to researchers to obtain useful data on the real appearance of the Zagros forests through investigative research. With this information, these forests can be guided toward sustainability through medium- and long-term planning. Many studies offer strategies to minimize deforestation, prevent forest land use change, increase sequestration by increasing forest growth, and reduce carbon emissions to maintain or strengthen forest carbon stock [6]. Therefore, in this study, the amount of carbon content in sacred grove and silvopastoral lands were investigated to determine a model of the capacity of Zagros oak forests in carbon sequestration and climate change reduction. The aim of this study was to estimate the amount of carbon reserves in mentioned land-uses in order to obtain a systematic attitude towards management of these different land-use types and attain a suitable solution to counter the climate change crisis and ultimately sustainable environmental development.

\section{Materials and Methods}

\section{Study site description}

The study area includes sacred groves and silvopastoral lands in Baneh County. This region is

97 embedded in North West part of Iran (In the Zagros Mountains) which is located within $35^{\circ} 48^{\prime}$

$9802^{\prime \prime}-36^{\circ} 11^{\prime} 40^{\prime \prime}$ north and $45^{\circ} 32^{\prime} 45^{\prime \prime}-46^{\circ} 10^{\prime} 25^{\prime \prime}$ East (Fig.1). The climate is semi-humid and cold, with long and cold winters and moderate summers. The average elevation was $1550 \mathrm{~m}$ and total precipitation recorded was $600-800 \mathrm{~mm}$. The average min. and max. Temperatures are -1.5 and $26.4^{\circ} \mathrm{C}$ respectively.

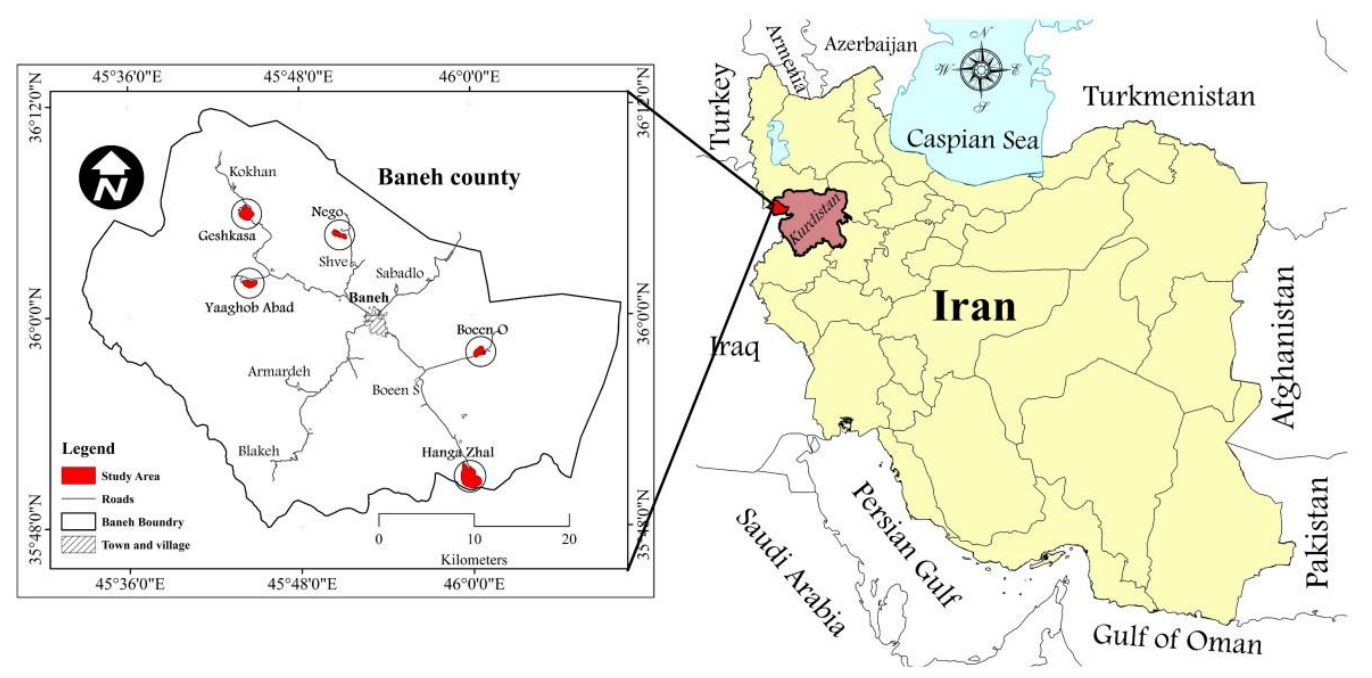

Fig. 1 Geographical location of the study area 
105 Dominant tree species are three kinds of oak, comprising Quercus brantii Lindel, Quercus libani 106 Olive and Quercus infectoria Olive. Species of Cerasus sp., Crataegus spp., Pistacia atlantica, 107 Amygdalus spp. and Lonicera sp. are the main companion woody species in these forests.

108 This study focused on 5 village's forests, include Hange Jal, Booien Olya, Nejo, Yaghoub Abad 109 and Gashkese, as five sites (Fig.1). In each selected sites, those cemeteries that had an area of more 110 than 1 hectare were selected as sacred groves. There are strict rules in the sacred groves that forbid 111 the cutting of trees, hunting, animal grazing, collecting herbage, firewood or other plant products. 112 Therefore this area includes less-disturbed forest stands. In fact, it can be said that these stands are 113 a view of real forests of the study area (Fig. 2). In order to compare the carbon content of sacred 114 groves with the exploited forests, the parts of the forests around these stands, that had the same 115 physiographic conditions with the sacred groves, were selected as Silvopastoral lands. This land 116 use is the forest that, Galazani system [22], livestock grazing and also some usages such as 117 harvesting the wood, is done by forest residents (Fig. 2).

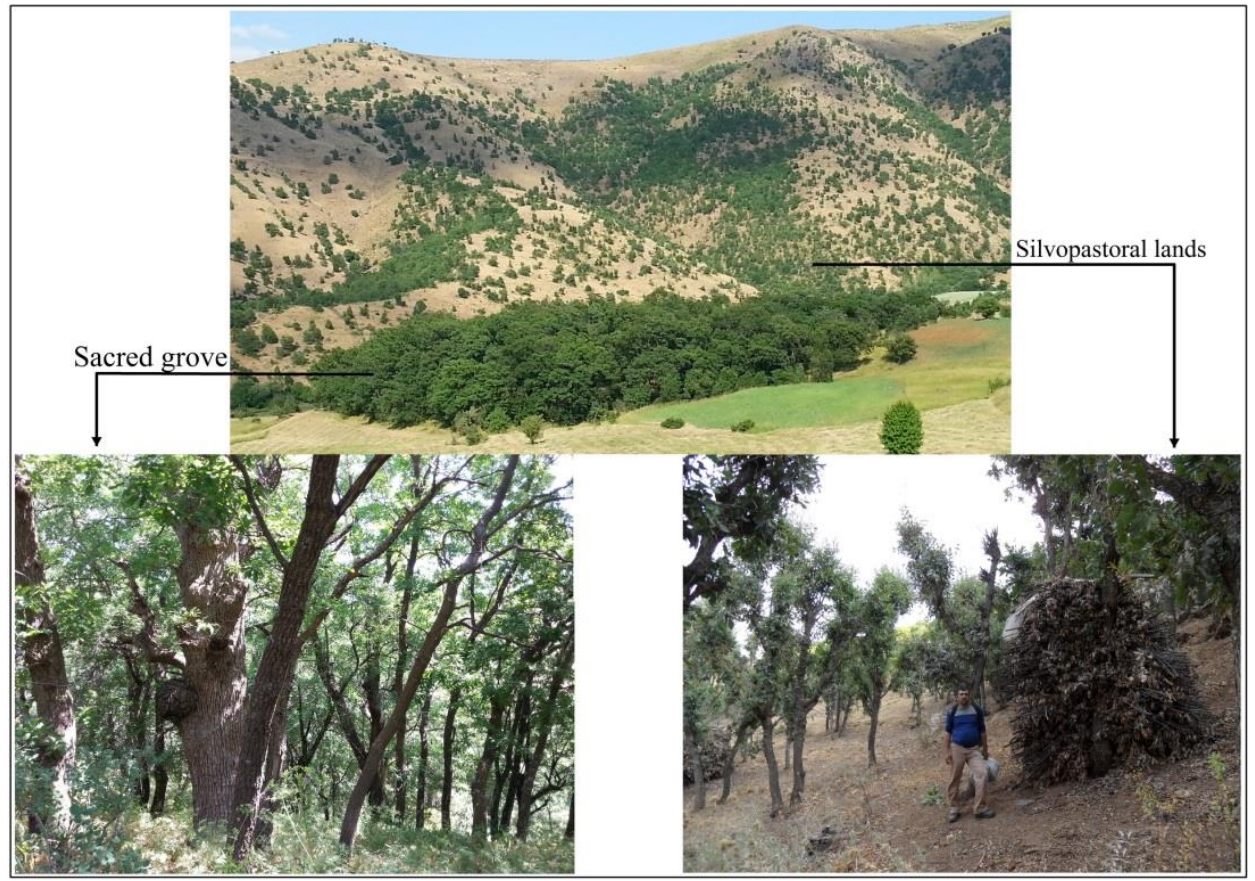

Fig 2 View of the two land uses studied (Sacred groves and Silvopastoral lands). 
123 The nested plot was used in the sampling design [3, 23]. As shown in Figure 3, in concentric nested 124 circular plots, multiple sub plots are settled for specific aims: a large circular plot (250 $\mathrm{m}^{2}$ with an 1258.2 m radius) was established for measure the trees. Inside of large plot, a sub plot (100 $\mathrm{m}^{2}$ with a $1265.65 \mathrm{~m}$ radius) was used to sapling measurement. Also, a sub-plot $\left(3.14 \mathrm{~m}^{2}\right.$ with a $1 \mathrm{~m}$ radius $)$ was 127 set up to count regeneration and a small sub plot ( $0.56 \mathrm{~m}$ radius) was established for collecting leaf 128 litter, herbs, grass, and soil samples.

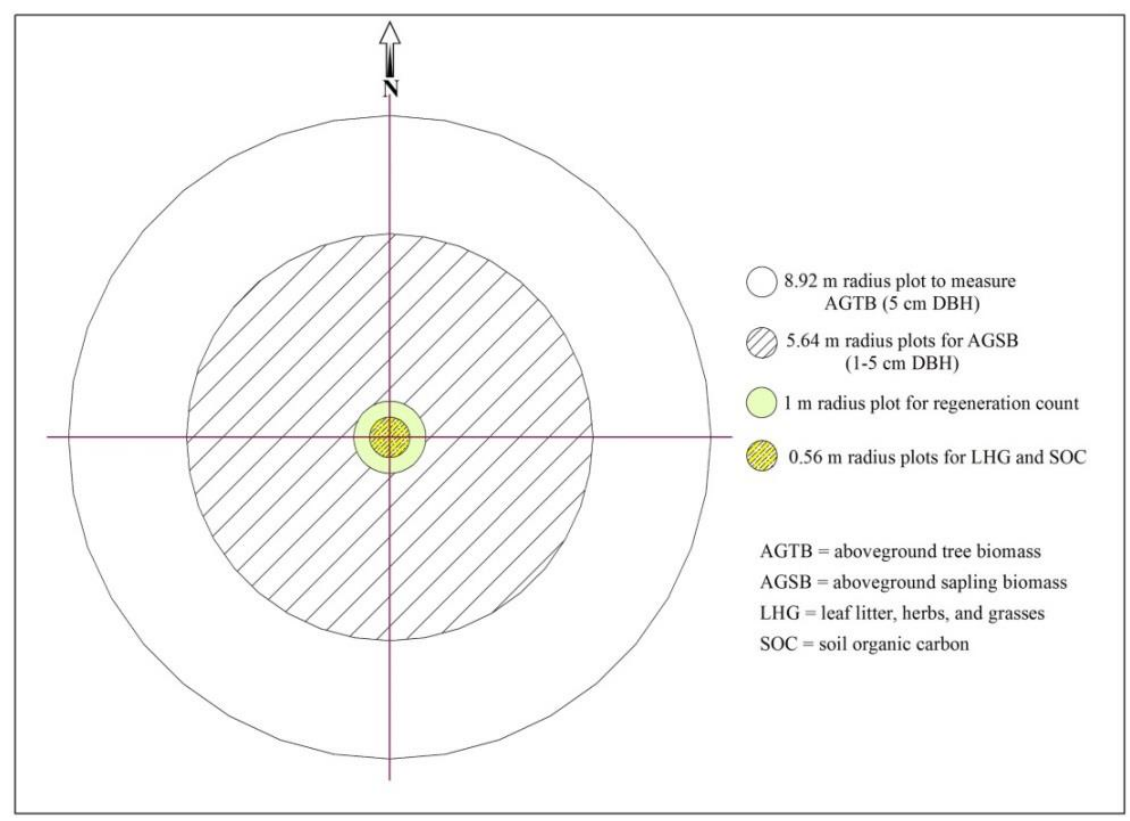

Fig. 3 Concentric nested circular plots

Measurement of forest carbon stock

133 Carbon pools measured in both land use include: Above-ground tree biomass (AGTB), Aboveground sapling biomass (AGSB), Below-ground biomass (BB), Soil organic carbon (SOC), Leaf litter, herbs, and grass (LHG) and Dead wood and fallen stumps (DWS). Therefore, the total carbon content for each land use was measured using the following equation [23]:

$141 \quad T C \quad=$ total carbon stock for each land use $\left[\mathrm{tC} \mathrm{ha}^{-1}\right]$ Where, 
$142 C(A G T B)=$ carbon content in aboveground tree biomass $\left[\mathrm{tC} \mathrm{ha}^{-1}\right]$

$143 C(A G S B)=$ carbon content in aboveground sapling biomass $\left[\left[\mathrm{tC} \mathrm{ha}^{-1}\right]\right.$

$144 C(L H G)=$ carbon content in leaf litter, herb and grass $\left[\mathrm{tC} \mathrm{ha}^{-1}\right]$

$145 C(B B)=$ carbon content in belowground biomass $\left[\mathrm{tC} \mathrm{ha}^{-1}\right]$

$146 \mathrm{C}(\mathrm{DWS})=$ carbon content in deadwood and stumps $\left[\mathrm{tC} \mathrm{ha}^{-1}\right]$

147 SOC = soil organic carbon $\left[\mathrm{tC} \mathrm{ha}^{-1}\right]$

148

149

Later, the total forest carbon stock was converted into carbon dioxide $\left(\mathrm{CO}_{2}\right)$ equivalent by

150 multiplying by 3.67 [24].

151 The methods for estimating carbon stock for each mentioned pools are explained in the following 152 sections.

153

154 Aboveground tree biomass (AGTB)

155 In both land use studied, the diameter at breast height $(\mathrm{DBH})$ and height of individual trees $(\geq 5 \mathrm{~cm}$ $156 \mathrm{DBH})$ were measured. Then all measured trees were recorded and classified according to species.

157 The biomass equation suggested by Chave et al. 2005 and ICIMOD et al. 2010, was used to 158 calculate the aboveground tree biomass. This equation (2) is as follows:

$$
A G T B=0.112 *\left(\rho \mathrm{D}^{2} \mathrm{H}\right)^{0.916}
$$

160 Where,

$161 \quad \mathrm{AGTB}=$ Above-ground tree biomass $[\mathrm{Kg}]$

$162 \rho=$ wood specific gravity $[\mathrm{g} \mathrm{cm}-3]$

$163 \mathrm{D}=$ Tree diameter at breast height $[\mathrm{cm}]$

$164 \mathrm{H}=$ Tree height $[\mathrm{m}]$

165 In both land use separately, the wood-specific density ( $\rho$ ) for different tree species was determined

166 in the laboratory. After attained the biomass stock density in $\mathrm{kg} \mathrm{m}^{-2}$, this value was multiplied by

16710 and converted to $\mathrm{tha}^{-1}$. Then, by multiplying the biomass content per 0.47 , the carbon stock 168 was obtained $[3,23,26]$.

\section{Above-ground sapling biomass (AGSB)}

170 All saplings with a diameter $1-5 \mathrm{~cm}$ were measured in sub-plot with a $5.64 \mathrm{~m}$ radius. The following 171 formula was used to obtain the stems biomass of sapling: 
174 Where,

175 AGSB $=$ Above-ground sapling biomass (stems biomass) $[\mathrm{Kg}]$

$176 \mathrm{D}=$ Sapling diameter $[\mathrm{cm}]$

$177 \mathrm{H}=$ Sapling height $[\mathrm{m}]$

$178 \mathrm{f} \quad=$ form quotient of Sapling (0.4)

$179 \rho \quad=$ wood specific gravity $\left[\mathrm{g} \mathrm{cm}^{-3}\right]$

180 The calculation of wood-specific density $(\rho)$ as well as the conversion of $\mathrm{kg} \mathrm{m}^{-2}$ to $\mathrm{t} \mathrm{h}^{-1}$ was 181 performed as mentioned in equation 2. Biomass value was converted to carbon stock using the 182 carbon fraction of $0.47[3,23,26]$.

\section{Leaf litter, herbs, and grass biomass (LHG)}

185 186

192 Where,

$193 \mathrm{LHG}=$ biomass of leaf litter, herb and grass $\left[\mathrm{t} \mathrm{ha}^{-1}\right]$

$194 \mathrm{~W}_{\text {field }}=$ weight of the fresh field sample of leaf litter, herb and grass $[\mathrm{g}]$

$195 \mathrm{~A}=$ Sample plot area in which leaf litter, herbs, and grass were gathered $\left[\mathrm{m}^{2}\right]$

$196 \mathrm{~W}_{\text {subsample, dry }}=$ weight of the oven-dry sample of leaf litter, herb and grass $[\mathrm{g}]$

$197 \mathrm{~W}_{\text {subsample, wet }}=$ weight of the fresh sample of leaf litter, herb and grass [g]

198 At the end, LHG carbon content was obtained by multiplying with the default carbon fraction 0.47. 
Belowground biomass (BB)

201 Belowground biomass (BB) is difficult to measure, time consuming and has a lot of uncertainty.

202 The following formula (5) has been proposed for estimating belowground biomass by Cairns et al.

203 1997. This equation is based on the relationship between belowground and aboveground biomass 204 and can be used for a variety of species and climatic conditions. In this study, the belowground biomass was calculated using this equation, which is as follows:

206

207

208

209

210

211 212

213

214

215

216

217

218

219

220

221

222

223

224

225

$$
B B=\exp [-1.085+0.9256 \times \ln (A G T B)]
$$

Where,

$\mathrm{BB}=$ Belowground biomass $[\mathrm{Kg}]$

AGTB $=$ Above-ground tree biomass $[\mathrm{Kg}]$

Finally, BB carbon content was calculated by multiplying with the default carbon fraction 0.47 .

\section{Dead wood and stumps (DWS)}

In the whole $250 \mathrm{~m}^{2}$ plots, all stumps from logged trees, standing dead trees, fallen stems, and fallen branches with a diameter at $\mathrm{DBH}$ and/or diameter $\geq 5 \mathrm{~cm}$ were measured. These dead parts of trees are important carbon pools that must be taken into account. Therefore, the diameter, length or height of each of the mentioned sections was recorded according to Instruction of ICIMOD et al. 2010 and Pearson et al. 2007. The amount of biomass and carbon obtained from this section was also calculated according to the mentioned instructions.

\section{Soil organic carbon (SOC)}

At each land-use site, a five plate center (sub-plot of $0.56 \mathrm{~m}$ radius) was chosen for soil sampling. Soil sampling was carried out separately at tow depths $(0-15$ and 10-30 $\mathrm{cm})$. Then, five well-mixed samples of soil for the first depth and five well-mixed samples of soil for the second depth (about $2 \mathrm{~kg}$ ) were prepared for each land use. Finally, 100 samples of prepared soil in plastic bags were transferred to laboratory $[28,29]$. To determine the percentage of soil organic carbon, 
226 the Walkley and Black (1934) method was employed [30, 31]. After measuring the percentage of

227 organic carbon, the amount of soil organic carbon stock at each depth was calculated separately

228 for each land-use type and site through the following formula [3, 23]:

229

$$
S O C=\rho \times \mathrm{d} \times \% C
$$

230 Where,

231 SOC $=$ soil organic carbon stock per unit area $\left[\mathrm{t} \mathrm{ha}^{-1}\right]$

$232 \rho=$ soil bulk density $\left[\mathrm{g} \mathrm{cm}^{-3}\right]$

$233 \mathrm{~d}=$ depth the soil sample was taken $[\mathrm{cm}]$

$234 \% C=$ carbon concentration [\%]

235

236

237

238

239

mean of the studied parameters in the two studied land use was performed by t-test (independent

240 samples t-test).

\section{Result}

In each of the two studied land use, 50 plots of $250 \mathrm{~m}^{2}$ were measured. Table 1 gives a detailed

244 summary of statistics for biomass and carbon as well as the results of T-test in the two studied land uses. The results showed that each of the studied variables in the two studied land use is

246 significantly different from each other $(\mathrm{P} \leq 0.01)$. The mean of each of these biomass or carbon 247 pools in silvopastoral is significantly lower than sacred groves. 
Table 1 Summary of statistics for biomass and carbon at the studied land uses

\begin{tabular}{|c|c|c|c|c|c|c|}
\hline \multirow{2}{*}{ Variables } & \multirow{2}{*}{ Land use } & \multirow{2}{*}{ Mean } & \multirow{2}{*}{$\begin{array}{l}\text { Standard } \\
\text { error }\end{array}$} & \multicolumn{3}{|c|}{ T-Test } \\
\hline & & & & $\mathrm{T}$ & $\mathrm{df}$ & Sig \\
\hline \multirow{2}{*}{ AGTB } & sacred groves & $348.63^{\mathrm{a}}$ & 31.15 & \multirow{2}{*}{8.79} & \multirow{2}{*}{98} & \multirow{2}{*}{0.000} \\
\hline & silvopastoral & $70.97^{b}$ & 5.1 & & & \\
\hline \multirow{2}{*}{ BB } & sacred groves & $63.3^{\mathrm{a}}$ & 5.27 & \multirow{2}{*}{9.27} & \multirow{2}{*}{98} & \multirow{2}{*}{0.000} \\
\hline & silvopastoral & $13.6^{\mathrm{b}}$ & 0.92 & & & \\
\hline \multirow{2}{*}{ AGSB } & sacred groves & $0.27^{\mathrm{a}}$ & 0.032 & \multirow{2}{*}{6.47} & \multirow{2}{*}{98} & \multirow{2}{*}{0.000} \\
\hline & silvopastoral & $0.05^{\mathrm{b}}$ & 0.009 & & & \\
\hline \multirow{2}{*}{$\begin{array}{l}\text { Herbs and } \\
\text { grass }\end{array}$} & sacred groves & $1.03^{\mathrm{a}}$ & 0.12 & \multirow{2}{*}{3.97} & \multirow{2}{*}{98} & \multirow{2}{*}{0.000} \\
\hline & silvopastoral & $0.42^{\mathrm{b}}$ & 0.09 & & & \\
\hline \multirow{2}{*}{ Leaf litter } & sacred groves & $11.55^{\mathrm{a}}$ & 0.82 & \multirow{2}{*}{7.70} & \multirow{2}{*}{98} & \multirow{2}{*}{0.000} \\
\hline & silvopastoral & $4.17^{\mathrm{b}}$ & 0.49 & & & \\
\hline \multirow{2}{*}{ DWS } & sacred groves & $29.04^{\mathrm{a}}$ & 7.09 & \multirow{2}{*}{4.06} & \multirow{2}{*}{98} & \multirow{2}{*}{0.000} \\
\hline & silvopastoral & $0.20^{\mathrm{b}}$ & 0.12 & & & \\
\hline \multirow{2}{*}{ TFBI } & sacred groves & $453.84^{\mathrm{a}}$ & 37.14 & \multirow{2}{*}{9.67} & \multirow{2}{*}{98} & \multirow{2}{*}{0.000} \\
\hline & silvopastoral & $89.43^{b}$ & 6.23 & & & \\
\hline \multirow{2}{*}{ TFC } & sacred groves & $213.3^{\mathrm{a}}$ & 17.45 & \multirow{2}{*}{9.67} & 98 & 0.000 \\
\hline & silvopastoral & $42.03^{\mathrm{b}}$ & 2.93 & & & \\
\hline TSC & sacred groves & $125.49^{\mathrm{a}}$ & 8.45 & 5.97 & 98 & 0.000 \\
\hline & silvopastoral & $71.44^{\mathrm{b}}$ & 3.23 & & & \\
\hline TC & sacred groves & $338.79^{a}$ & 20.89 & 1053 & 08 & 0,000 \\
\hline IC & silvopastoral & $113.48^{\mathrm{b}}$ & 4.51 & 10.53 & 98 & 0.000 \\
\hline
\end{tabular}

253 In the next sections, the pools of forest biomass and carbon stocks measured in the two land use 254 are briefly reported. amount is related to the AGSB. The difference between the amounts of DWS biomass in the two

263 land use is significant; so that its amount was more in the sacred groves (table 2). Another 
264 important difference was that, the LHG biomass value in the sacred groves was significantly higher

265 than the silvopastoral, but the proportion of LHG biomass in total biomass was higher in the 266 silvopastoral lands.

Table 2 Biomass value and its proportion at the studied land uses

\begin{tabular}{ccccc}
\hline \multirow{2}{*}{ Variables } & \multicolumn{2}{c}{ Sacred groves } & \multicolumn{2}{c}{ Silvopastoral } \\
\cline { 2 - 5 } & $\begin{array}{c}\text { Biomass } \\
\text { value (tha }{ }^{-1)}\end{array}$ & Proportion & $\begin{array}{c}\text { Biomass } \\
\text { value (tha }\end{array}$ & Proportion \\
\hline AGTB & 348.63 & $\mathbf{7 6 . 8 2}$ & 70.97 & $\mathbf{7 9 . 3 8}$ \\
BGB & 63.30 & $\mathbf{1 3 . 9 5}$ & 13.61 & $\mathbf{1 5 . 2 2}$ \\
ABSB & 0.27 & $\mathbf{0 . 0 6}$ & 0.05 & $\mathbf{0 . 0 6}$ \\
LHG & 12.59 & $\mathbf{2 . 7 7}$ & 4.58 & $\mathbf{5 . 1 2}$ \\
DWS & 29.04 & $\mathbf{6 . 4 0}$ & 0.20 & $\mathbf{0 . 2 2}$ \\
TFBI & 453.83 & $\mathbf{1 0 0 . 0 0}$ & 89.41 & $\mathbf{1 0 0 . 0 0}$ \\
\hline \multicolumn{3}{c}{ TFBI: Total forest biomass }
\end{tabular}

\section{Carbon content}

271 As shown in table 1, the carbon content in each of the carbon pools in the two studied land uses

272 were significantly different from each other. The average total carbon content was estimated to be

$273 \quad 338.79 \mathrm{tC} \mathrm{ha}^{-1}$ and $113.46 \mathrm{tC} \mathrm{ha}^{-1}$ respectively in the sacred grove and silvopastoral lands. Carbon

274 proportion in carbon pools is not the same in two studied land uses, unlike the similar distribution

275 of biomass content (table 3). The AGTB and soil had maximum share of the total forest carbon

276 stock, while the ABSB contributed the lowest share in both land use. Average soil organic carbon

277 was significantly lower $\left(71.44 \mathrm{tC} \mathrm{ha}^{-1}\right)$ in silvopastoral lands, than in sacred groves $\left(125.49 \mathrm{tC} \mathrm{ha}^{-}\right.$

$\left.278{ }^{1}\right)$. The important point was that, unexpectedly, in silvopastoral lands the soil carbon value $(62.96 \%$

279 of total carbon) is higher than that of above-and belowground carbon (37.04\% of total carbon)

280 (Fig. 4). 
281 The mean total sequestered carbon dioxide $\left(\mathrm{CO}_{2}\right)$ was $1243.36 \mathrm{tCO}_{2} \mathrm{~h}^{-1}$ in sacred grove and 416.4

$282 \mathrm{tCO}_{2} \mathrm{~h}^{-1}$ in silvopastoral lands. This is a significant reduction, i.e. the reduction of carbon dioxide

283 absorption capacity in forests by incorrect operations.

284

285

Table 3 Carbon content and its proportion at the studied land uses

\begin{tabular}{ccccc}
\hline \multirow{2}{*}{ Variables } & \multicolumn{2}{c}{ Sacred groves } & \multicolumn{2}{c}{ Silvopastoral } \\
\cline { 2 - 5 } & $\begin{array}{c}\text { Carbon } \\
\text { content }\left(\text { tha }^{-1)}\right.\end{array}$ & Proportion & $\begin{array}{c}\text { Carbon } \\
\text { content }\left(\text { tha }^{-1)}\right.\end{array}$ & Proportion \\
\hline AGTB & 163.86 & 48.37 & 33.36 & 29.40 \\
BGB & 29.75 & 8.78 & 6.39 & 5.64 \\
ABSB & 0.13 & 0.04 & 0.02 & 0.02 \\
LHG & 5.92 & 1.75 & 2.15 & 1.90 \\
DWS & 13.65 & 4.03 & 0.09 & 0.08 \\
\hline TFC & $\mathbf{2 1 3 . 3 0}$ & $\mathbf{6 2 . 9 6}$ & $\mathbf{4 2 . 0 2}$ & $\mathbf{3 7 . 0 4}$ \\
\hline TSC & $\mathbf{1 2 5 . 4 9}$ & $\mathbf{3 7 . 0 4}$ & $\mathbf{7 1 . 4 4}$ & $\mathbf{6 2 . 9 6}$ \\
\hline TC & 338.79 & 100.00 & 113.46 & 100.00 \\
\hline TFC: Total forest Carbon; TSC: Total soil organic carbon and TC: Total carbon
\end{tabular}

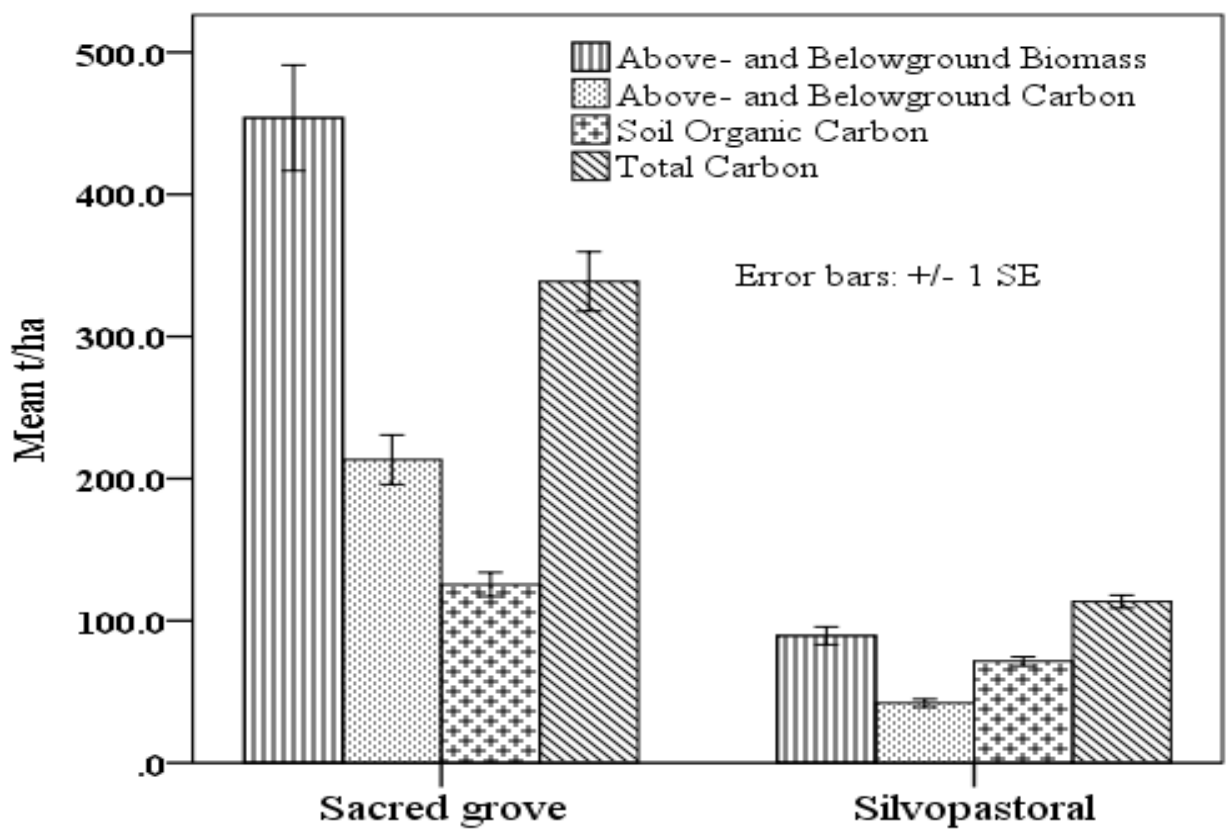

Land use

Fig 4 Comparison of studied variables in two land use 
292 Rising atmospheric carbon dioxide has led to the global consequences of climate change. 293 Biological carbon sequestration through vegetation and soil is one of the cost-effective ways to 294 reduce this gas [32]. Forests are one of the most important elements of the global carbon cycle 295 [33]. Carbon deposits in the forest include plant biomass and carbon in the soil. In the present 296 study, for the first time, the amount of biomass and carbon storage in sacred groves in Zagros 297 forests were estimated and compared. Aboveground biomass as well as the amount of carbon in 298 all carbon pools in sacred groves was significantly higher than silvopastoral lands. There was no 299 human intervention in sacred groves and so in this land use, multi-storey tree cover, trees with 300 great height and diameter, dense canopy, abundant leaf litter, high deadwood, rich grass cover 301 under the canopy and species diversity led to very favorable conditions. However, grazing 302 traditionally occurs in silvopastoral lands. Because animal husbandry is carried out using 303 traditional methods, in addition to the grass cover of the forest floor, the branches and leaves of 304 the trees in these forests are used for grazing livestock through the pollarding system. In this land 305 use, the tree production and growth capability was reduced due to pollarding. The low foliage 306 production, forest floors bare of leaf litter, poor grass cover, high soil erosion and soil surface 307 compaction consequently lead to poor biomass and equilibrium of carbon inputs and storage which 308 were much lower than expected in the silvopastoral lands under study.

309 The amount of carbon stored in plants is strongly related to the amount of biomass [7]. The higher 310 the production capacity of above- and belowground biomass in different species and habitats, the 311 higher the carbon storage in the body of trees, leaf litter and soil.

312 When the density of the forest changes under the influence of human intervention, the amount of 313 carbon per unit area also changes [16]. Therefore, the significant difference between biomass and 
314 carbon in the two studied uses was due to human intervention. These mismanaged interventions 315 significantly reduced the amount of biomass and carbon associated with it.

316 Various studies have shown that carbon is stored in different parts of the forest ecosystem, mostly 317 in wood [7, 34]. In this study, in the above- and belowground biomass section, the highest carbon 318 percentage was in the AGTB section, but in the sacred groves it was significantly higher than 319 silvopastoral lands. Another important point is the percentage of each carbon pool in the total 320 carbon stored. In sacred groves, the percentage of total carbon in above- and belowground was $32162.96 \%$ while the percentage of soil carbon was $37.04 \%$. In total contrast, in silvopastoral lands, 322 the percentage of soil carbon was greater (62.96) than the percentage of total carbon above- and 323 below-ground (37.04). This indicates a decrease in tree density, seedlings and regeneration and 324 much destruction due to improper use of silvopastoral lands.

325 The amount of soil carbon in sacred groves was approximately 1.8 times that of silvopastoral lands. 326 The change in the amount of soil carbon sequestration depends on the amount of carbon entering 327 the soil through plant debris and the amount of carbon loss through decomposition [35]. Many 328 researchers [1, 35-37], have pointed to the relationship between soil organic carbon sequestration 329 and vegetation percentage, leaf litter and crop residues, land use and management. The significant 330 difference of soil carbon in the two land uses studied in this study was also due to the difference 331 in the return of organic matter to the soil and its small amount in silvopastoral lands. The results 332 of this study indicate that sacred groves with high biodiversity are part of the Zagros forests. In 333 fact, if the forests of the Zagros were less degraded or properly managed, they would be in a similar 334 situation to sacred groves today. If this were the case, these forests would have a greater impact 335 on carbon sequestration and climate change. Sacred grove use currently absorbs 826.96 tons of 336 carbon dioxide per hectare more than silvopastoral lands and this is a sign of high degradation in 
337 the forests of the study area. Appropriate management would prevent further degradation and make use of the good potential of these forests to reduce atmospheric gases through carbon sequestration.

\section{Conclusions}

341 Forest ecosystems have the greatest potential for atmospheric carbon sequestration. Improper

342 human intervention in forest ecosystems accelerates the process of global warming. Accelerating 343 global warming is the most important factor in future climate change. According to the results 344 obtained in this study, forest ecosystems that are protected against human intervention play a 345 significant role in long-term carbon storage. Any interference with the natural conditions of the 346 ecosystem has a significant negative impact on carbon reserves. Therefore, by selecting 347 appropriate measures, local communities should be empowered to reduce their dependence on low 348 incomes obtained from deforestation and conversion. In addition to carbon storage, sacred groves 349 are the most important centers for biodiversity conservation as more formal methods for protected 350 areas have often failed. The number of sacred groves in the forests of the North Zagros is 351 significant. According to the above, the Zagros forests in western Iran have essential carbon 352 reserves and biodiversity that are of great environmental importance. Taking into consideration 353 the vast and significant area of the Zagros forests in western Iran, the role of this natural and 354 valuable ecosystem in dealing with recent climate change becomes more apparent. 


\section{Abbreviations}

AGTB: Above-ground tree biomass; AGSB: Above-ground sapling biomass; BB: Below-ground biomass; SOC: Soil organic carbon; LHG: Leaf litter, herbs, and grass; DWS: Dead wood and fallen stumps; TC: Total carbon stock; DBH: Diameter at breast height; $\rho$ : wood-specific density. Availability of data and materials

The datasets used and/or analyzed during the current study are available from the corresponding author on reasonable request.

\section{Competing interests}

The authors declare that they have no competing interests.

\section{Funding}

This study was a Postdoctoral project in university of Kurdistan (Iran) and supported by a grant from this university.

\section{Author contributions statement}

AM designed the research, gathered and analyzed the data under scientific advice of Dr. N Sh. AM wrote the manuscript and N Sh. thoroughly reviewed and edited the manuscript. Compliance with ethical standards

\section{Acknowledgements}

Not applicable

\section{References}

1. PahlavanYali Z, Zarrinkafsh M, Moeini A. Quantitative Estimation of Soil Carbon Sequestration in Three Land Use Types (Orchard, Paddy Rice and Forest) in a Part of Ramsar Lands, Northern Iran. J Water Soil. 2016;30(3):758-768.

2. Johnsen KH, Wear D, Oren R, Teskey RO, Sanchez F, Will R, Butnor J, Markewicz D, et al. Meeting globalpolicy commitments: Carbon sequestration and southern pine forests. JOF. 2001;99(4):14-2.

3. Karki S, Joshi NR, Udas E, Adhikari MD, Sherpa S, Kotru R, Karky BS, Chettri N, Ning W. Assessment of Forest Carbon Stock and Carbon Sequestration Rates at the ICIMOD Knowledge Park in Godavari. ICIMOD. 2016;41p.

4. Fargione JE, Bassett S, Boucher T, Bridgham SD, Conant RT, Cook-Patton SC, Ellis PW, Falcucci 
A, Fourqurean JW, Gopalakrishna T, et al. Natural climate solutions for the United States. Sci. Adv. 2018;4:1-15. https://doi.org/10.1126/sciadv.aat1869

5. Griscom BW, Adams J, Ellis PW, Houghton RA, Lomax G, Miteva DA, Schlesinger WH, Shoch D, Siikamäki JV, Smith P, Woodbury P, et al. Natural climate solutions. Proc. Natl. Acad. Sci. U. S. A. 2017;114:11645-11650. https://doi.org/10.1073/pnas.1710465114

6. Ontl TA, Janowiak MK, Swanston CW, Daley J, Handler S, Cornett, M, Hagenbuch S, Handrick C, Mccarthy L, Patch N. Forest Management for Carbon Sequestration and Climate Adaptation. J. For. 2020;118: 86-101. https://doi.org/10.1093/jofore/fvz062

7. Wegiel A, Polowy, K. Aboveground Carbon Content and Storage in Mature Scots Pine Stands of Different Densities. Forests. 2020;11(2) 240. https://doi:10.3390/f11020240

8. Zhang M, Du H, Zhou G, Li X, Mao F, Dong L, Zheng J, Liu H, Huang Z, He S. Estimating Forest Aboveground Carbon Storage in Hang-Jia-Hu Using Landsat TM/OLI Data and Random Forest Model. Forests. 2019;10(11):1004. https://doi.org/10.3390/f10111004

9. Pan Y, Birdsey RA, Fang J, Houghton R, Kauppi PE, Kurz WA, Phillips OL, Shvidenko A, Lewis SL, et al. A Large and Persistent Carbon Sink in the World's Forests. Science. 2011;333:988-993.

10. Santini NS, Adame MF, Nolan RH, Miquelajauregui Y, Piñero D, Mastretta-Yanes A, CuervoRobayo ÁP, Eamus D. Storage of organic carbon in the soils of Mexican temperate forests. For. Ecol. Manag. 2019;446:115-125. https://doi.org/10.1016/j.foreco.2019.05.029

11. Lin B, Ge J. Valued forest carbon sinks: How much emissions abatement costs could be reduced in China. J. Clean. Prod. 2019;224:455-464. https://doi.org/10.1016/j.jclepro.2019.03.221

12. Labrecque S, Fournier R, Luther J, Piercey D. A comparison of four methods to map biomass from Landsat-TM and inventory data in western Newfoundland. For. Ecol. Manag. 2006;226:129-144. https://doi.org/10.1016/j.foreco.2006.01.030

13. Rebane S, Jõgiste K, Kiviste A, Stanturf JA, Metslaid M. Patterns of Carbon Sequestration in a Young Forest Ecosystem after Clear-Cutting. Forests. 2020;11(2):126. https://doi.org/10.3390/f11020126

14. Köster K, Köster E, Orumaa A, Parro K, Jõgiste K, Berninger F, Pumpanen J, Metslaid M. How Time since Forest Fire Affects Stand Structure, Soil Physical-Chemical Properties and Soil CO2 Efflux in Hemiboreal Scots Pine Forest Fire Chronosequence? Forests. 2016;7(9):201. https://doi.org/10.3390/f7090201 
15. Parro K, Koster K, Jogiste K, Seglins K, Sims A, Stanturf JA, Metslaid M. Impact of post-fire management on soil respiration, carbon and nitrogen content in a managed hemiboreal forest. J. Environ. Manag. 2019;233:371-377. https://doi.org/10.1016/j.jenvman.2018.12.050

16. Fragoso-López PI, Rodríguez-Laguna R, Otazo-Sánchez EM, González-Ramírez CA, ValdézLazalde JR, Cortés-Blobaum HJ, Razo-Zárate R. Carbon Sequestration in Protected Areas: A Case Study of an Abies religiosa (H.B.K.) Schlecht. et Cham Forest. Forests. 2017;8(11):429. https://doi.org/10.3390/f8110429

17. Plieninger T, Quintas-Soriano C, Torralba M, Mohammadi Samani K, Shakeri Z. Social dynamics of values, taboos and perceived threats around sacred groves in Kurdistan, Iran. People Nat. 2020;2:1237- 1250. https://doi.org/10.1002/pan3.10158

18. Watson J, Dudley N, Segan D, Hockings, M. The performance and potential of protected areas. Nature. 2014;515:67-73. https://doi.org/10.1038/nature13947

19. Pungetti G, Oviedo G, Hooke D. Sacred species and sites: Advances in biocultural conservation. Cambridge University Press. 2012;472p.

20. Jazirehi MH, Ebrahimi Rostaghi M. Silviculture in Zagros. University of Tehran Press. 2013;560p.

21. Shakeri Z, Silvicultural and Ecological Effect of Galazani on Oak Trees in Baneh Forest (Kurdistan Province NW Iran). M.Sc. thesis in Forestry, Tehran University. 2007;65p.

22. Valipour A, Plieninger T, Shakeri Z, Ghazanfari H, Namiranian M, Lexer MJ. Traditional silvopastoral management and its effects on forest stand structure in northern Zagros, Iran. Forest Ecol Manag. 2014;327:221-230. https://doi.org/10.1016/j.foreco.2014.05.004

23. ICIMOD, ANSAB, FECOFUN. Forest carbon measurement guidelines. Kathmandu, Nepal: ICIMOD. 2010;67p.

24. Pearson TR, Brown SL, Birdsey RA. Measurement guidelines for the sequestration of forest carbon. US: Northern Research Station, Department of Agriculture. 2007. http://www.nrs.fs.fed.us/pubs/gtr/gtr_nrs18.pdf (accessed 27 May 2010)

25. Chave J, Andalo C, Brown S, Cairns MA, Chambers JQ, Eamus D. Tree allometry and improved estimation of carbon stocks. Oecologia. 2005;87-99. https://doi.org/10.1007/s00442-005-0100-x

26. Sumarga E, Nurudin N, Suwandhi I. Land-Cover and Elevation-Based Mapping of Aboveground Carbon in a Tropical Mixed-Shrub Forest Area in West Java, Indonesia. Forests. 2020;11(6):636 
https://doi.org/10.3390/f11060636

27. Cairns MA, Brown S, Helmer EH, Baumgardner GA. Root biomass allocation in the world's upland forests. Oecologia. 1997;111(1):1-11. https://doi.org/10.1007/s00442005020

28. Gao Y, Schumann M, Chen $\mathrm{H}, \mathrm{Wu} \mathrm{N}$, Luo, P. Impacts of grazing intensity on soil carbon and nitrogen in an alpine meadow on the eastern Tibetan Plateau. J FOOD AGRIC ENVIRON. 2009;7(2):749-754.

29. Paul KI, Polglase PJ, Nyakuengama JG, Khanna PK. Change in soil carbon following afforestation. For. Ecol. Manag. 2002;168:241-257. https://doi.org/10.1016/S0378-1127(01)00740-X

30. Nosetto MD, Jobbagy EG, Paruelo JM. Carbon sequestration in semi-arid rangelands: Comparison of Pinus ponderosa plantations and grazing exclusion in NW Patagonia. J Arid Environ. 2006;67:142-156. https://doi.org/10.1016/j.jaridenv.2005.12.008

31. Amanuel W, Yimer F, Karltun E. Soil organic carbon variation in relation to land use changes: The case of Birr watershed, upper Blue Nile River Basin, Ethiopia. Ecol. Environ. 2018;42(16). https://doi.org/10.1186/s41610-018-0076-1

32. Johnsen KH, Wear D, Oren R,Teskey RO, Sanchez F, Will R, Butnor J, Markewicz D, Richter D, Rials T, Allen HL, Seiler J, Ellsworth D, Maier C, Samuelson L, Katul D, Philougherty G. Meeting globalpolicy commitments : Carbon sequestration and southern pine forests. Journal of Forestry. 2001;99(4).

33. Aris D. Calibration of LAI-2000 to estimate leaf area index and assessment of its relationship with stand productivity in six native and introduced tree species in Costa Rica. For. Ecol. Manag. 2007;247(1):185-193.

34. Dewar RC, Cannell MG. Carbon sequestration in the trees, products and soils of forest plantations: an analysis using UK examples, Tree Physiol. 1992;11(1):49-71 https://doi.org/10.1093/treephys/11.1.49

35. Rice CW. Carbon Cycle in Soils - Dynamics and Management. Encyclopedia of Soils in the Environment. 2004;4:164-170. https://doi.org/10.1016/B0-12-348530-4/00183-1

36. Singh G, Bala N, Chaudhuri K, Meena R. Carbon Sequestration Potential of Common Access Resources in Arid and Semi-arid Regions of Northwestern India. Indian For. 2003;129: 859-864.

37. Salehi A, Noormohammadi E. Effect of grazed and surface scrafication on soil properties and 
regeneration in centeral Zagros forests (Case study: Aleshtar city forests). J For Wood Prod. 2012;65:315-325.

482

38. Varamesh S. Comparison of Carbon Sequestration in Broad Leaved and Needle Leaved Species in

483 Urban Forest (Case study: Chitgar park of Tehran). M.Sc. thesis in Forestry, Tarbiat Modares University. 2009;130p 
Figures

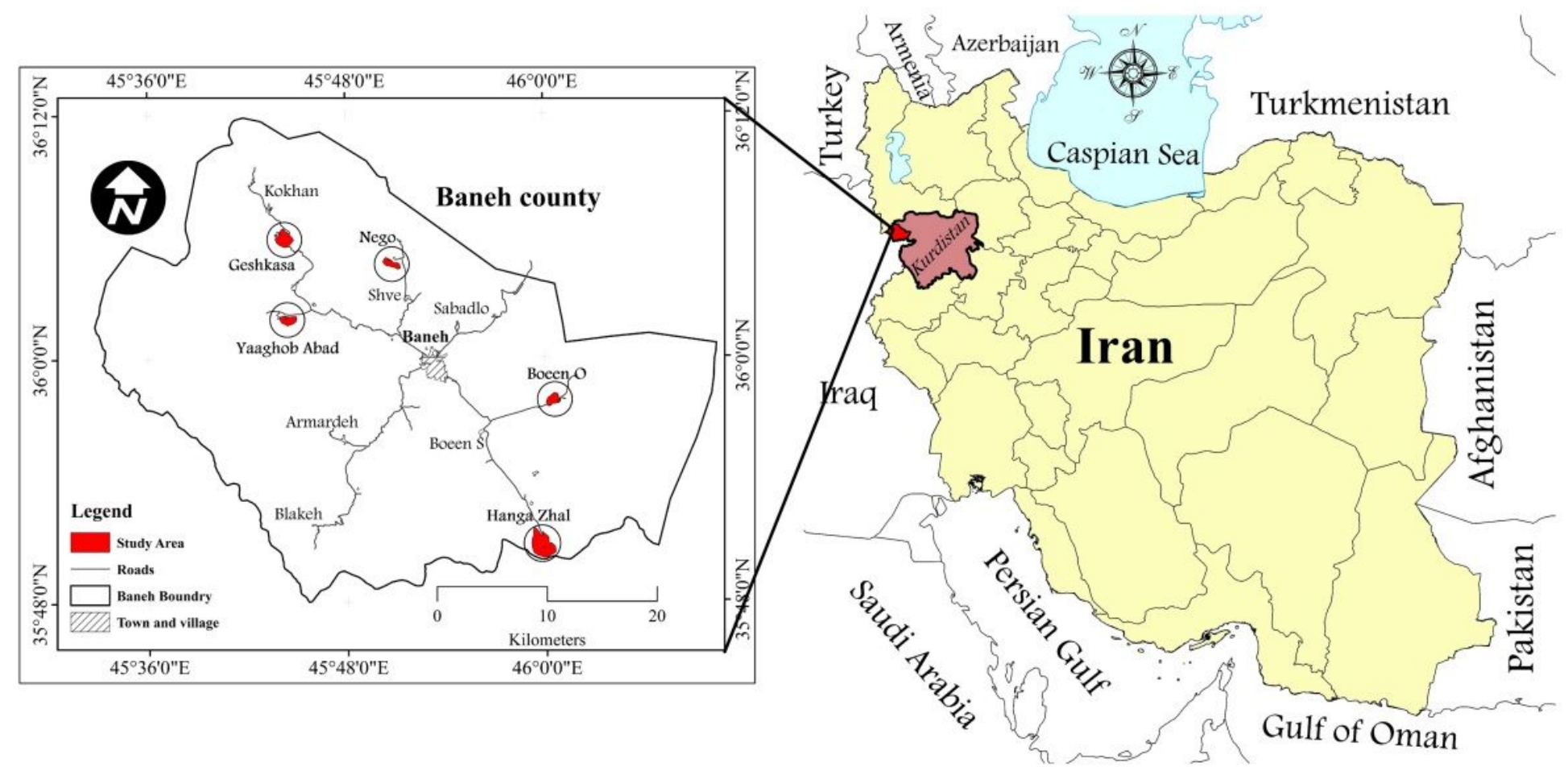

\section{Figure 1}

Geographical location of the study area Note: The designations employed and the presentation of the material on this map do not imply the expression of any opinion whatsoever on the part of Research Square concerning the legal status of any country, territory, city or area or of its authorities, or concerning the delimitation of its frontiers or boundaries. This map has been provided by the authors. 


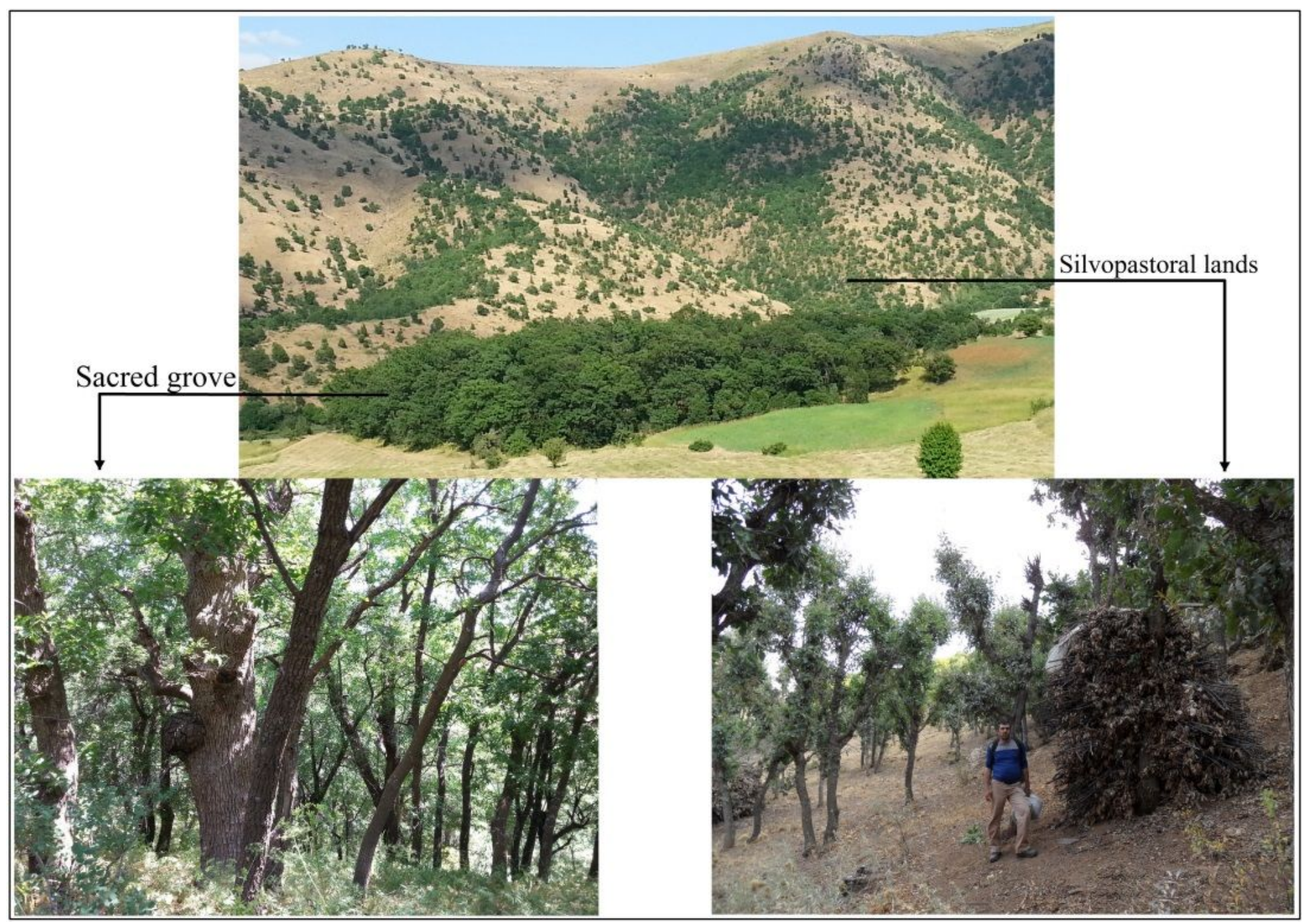

Figure 2

View of the two land uses studied (Sacred groves and Silvopastoral lands). 


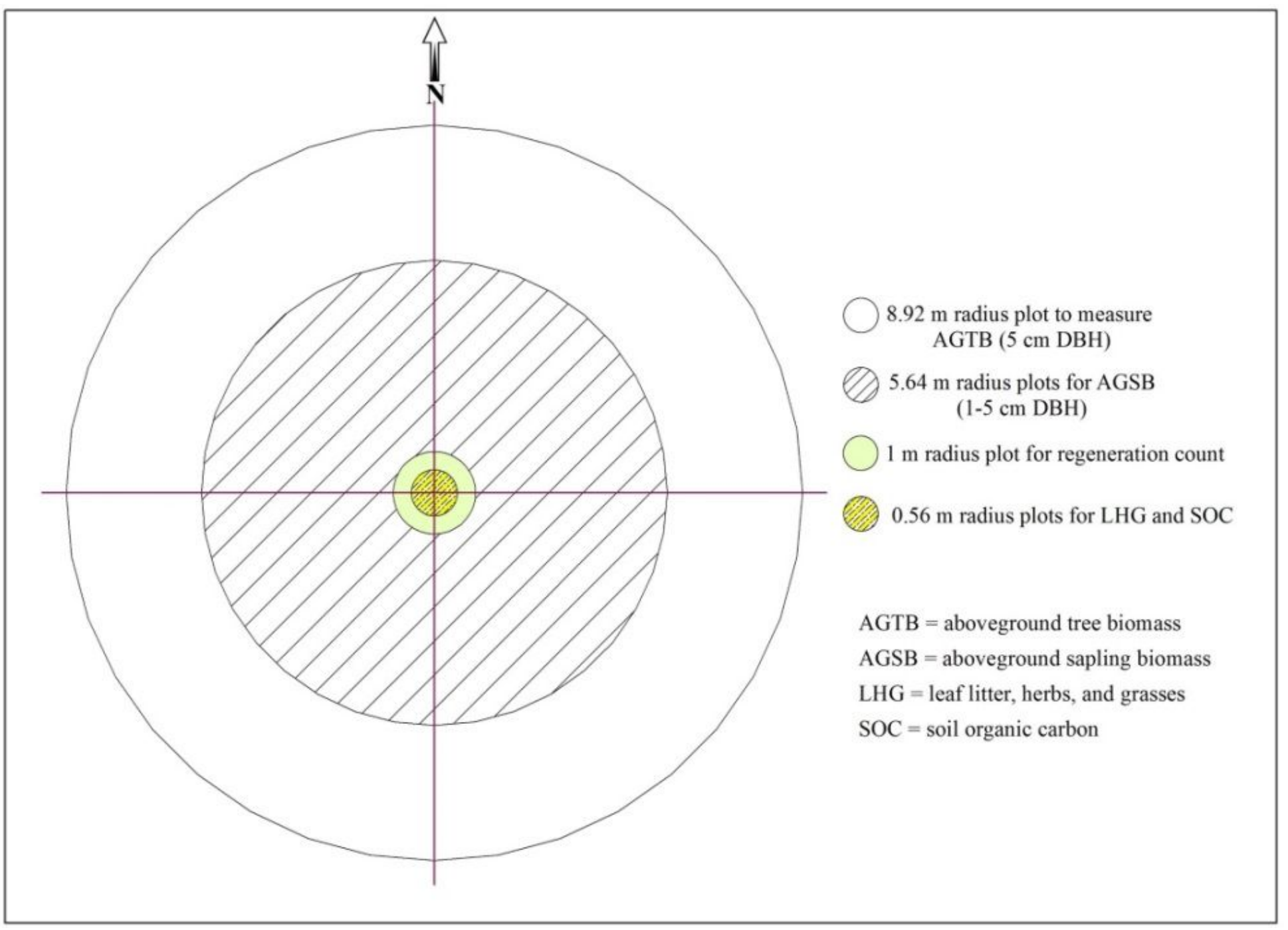

\section{Figure 3}

Concentric nested circular plots 


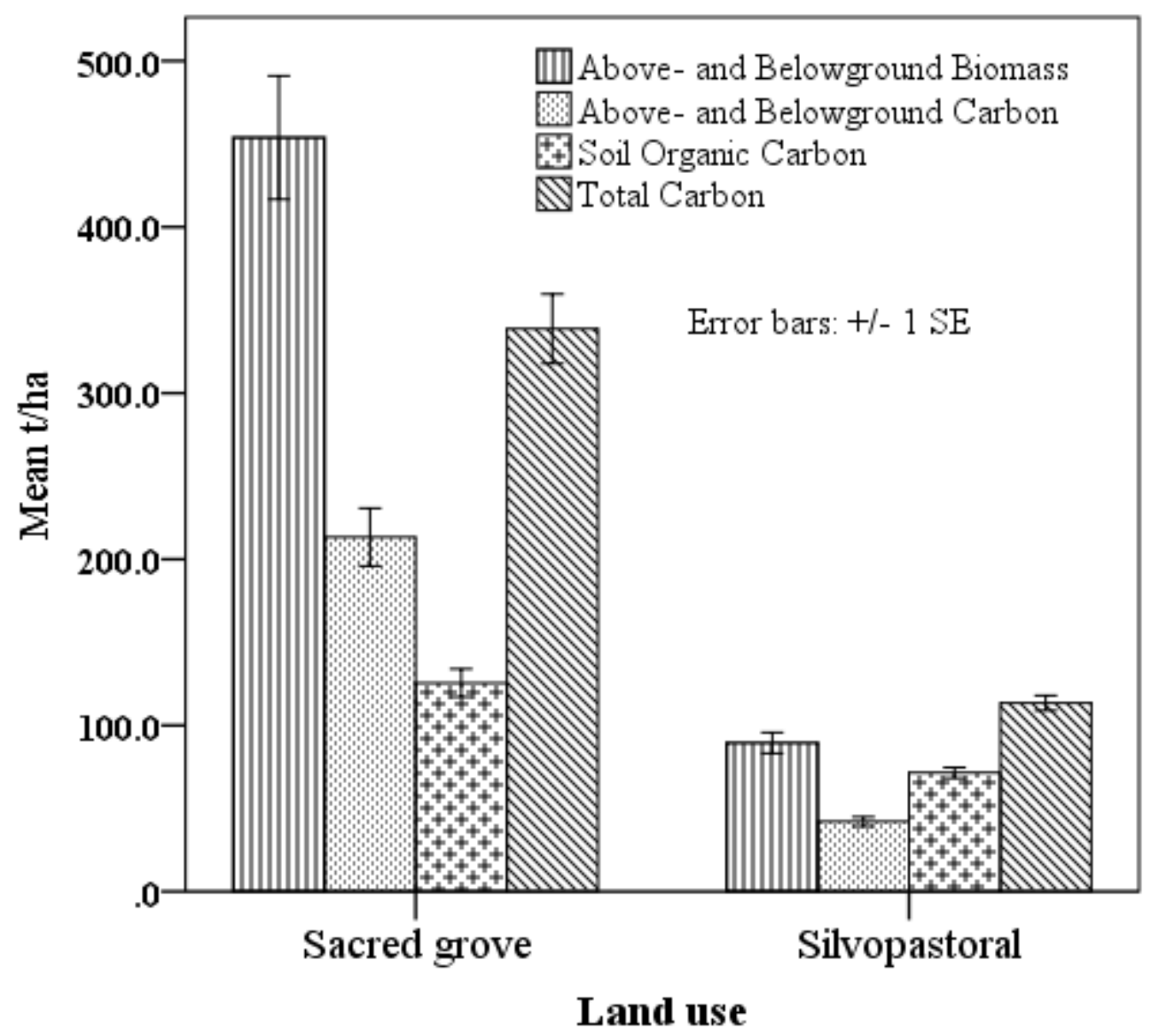

Figure 4

Comparison of studied variables in two land use 